\title{
Bush badly needs good advice
}

President George Bush has promised to create better machinery for gathering technical advice, but time is passing. A search for a paragon should not let him hide from the urgency of his need.

THE new president of the United States may be saying all the right things (see Nature 337,$585 ; 1989$ ), but he is doing fewer of them than he should. This complaint has been levelled generally at the new administration, which has yet to fill its roster of cabinet appointments, let alone all the second-rank posts, all of whose incumbents will have to be interviewed by a committee of the Senate and judged capable of doing their jobs. But the complaint is particularly apt when applied to President Bush's plans for the more effective administration of science, among the most ambitious of those put forward last month.

Briefly, Bush would give a new science adviser the status of "assistant to the President", putting him or her on a par with the head of the National Security Agency (now General Brendt Scowcroft). On top of that, there is to be a Council of Science and Technology Advisors resembling in all but name what used to be the President's Science Advisory Committee (PSAC), much respected until killed off by President Richard M. Nixon. But nobody has yet been nominated for the top job. Even if a name should have appeared before the end of this week, a quarter of a year (or a sixteenth of a presidential term) will have gone before the man or woman can set to work.

The administration's general excuse for its tardiness that its succession of the like-minded Reagan administration means fewer policy discontinuities and thus a lesser need of new officials - does not apply to the science advisory job which, as advertised, is an innovation. The present holder of the office, Mr William Graham, has had only meagre influence during his two years, and is unlikely to be struggling for promotion.

So why not pick somebody and get on with it? The word is that the administration is looking for a science adviser from industry, which is consistent with the Bush view of science as a means of improving the competitiveness of the United States in the "global marketplace". One snag is the formidable list of loyalty tests the new incumbent will have to survive: finding a Republican will be easy, finding somebody willing to go to the stake for the Strategic Defense Initiative will be something else.

A more practical difficulty may be that there is already a technical person powerfully placed at the White House. Mr John Sununu, Bush's chief of staff, was a chemical engineer before becoming governor of New Hampshire. Between gaps in what must be the fullest appointments diary in the Western world, not to mention side-trips to
Japan, China and Korea, Sununu is interviewing potential candidates for the new job. Quite apart from his lack of time, there may be a further difficulty: some putative incumbents may be deterred by knowing that the man who allocates space in Bush's working day is likely to have his own strong views on what science advice the president should be given.

Yet the need for an appointment becomes more urgent every day. In just over two months, the National Security Council is to have completed a review of US policy on national security, to which an able science adviser would have a powerful contribution to make.

Soon afterwards, early in the summer, there will be a ministerial meeting of the North Atlantic Treaty Organization that will be crucial for the future of US weapons policy. Meanwhile, the administration is being challenged by the daunting character of its own agenda (improving public education, doing something effective about AIDS and drugs) as well as by the conundrums thrown up by the Congress, the still-unfocused worry about climatic change for example (see page 3 ). The danger is that too many of these issues will be decided by default.

The reconstitution of PSAC will raise other problems. From its creation after the Second World War until its abolition, the old PSAC won respect by the self-evident independence of its members. Sometimes it could be an irritating talking-shop, but its strength was its readiness to oppose administration policy when it thought fit. Bush is looking for a council of "leading scientists, engineers and distinguished executives from the private sector" (which includes the universities), which is not in itself a bad prescription. But will he allow that the advisers should be chosen for the calibre of the advice they have to offer, not the likelihood that the advice will be acceptable? That will be the acid test of whether Bush means all the right things he is saying.

\section{Science squeezed}

Nobody should be surprised that ten years of short commons have deprived Britain of researchers.

THE emergence in Britain of a shortage of young researchers (see page 7) is about as remarkable as the diurnal rhythm. For close on ten years, British research 